Article

\title{
The Impacts of the Energy Potential of Forest Biomass on the Local Market: An Example of South-Eastern Poland
}

\author{
Tomasz Dudek (D) \\ Department of Agroecology, University of Rzeszów, Ćwiklińskiej 1a, 35-601 Rzeszów, Poland; \\ tdudek80@ur.edu.pl
}

Received: 26 August 2020; Accepted: 22 September 2020; Published: 22 September 2020

\begin{abstract}
Forest biomass is and will remain a primary source of renewable energy in many EU countries in the coming years. The aim of this study was to determine the energy potential of forest biomass on a regional scale with regard to the needs of its inhabitants in terms of electricity and heat consumption. The study was carried out in south-eastern Poland. Energy potential was calculated based on the determined wood mass and calorific value of wood. The current level of forest biomass acquisition satisfies $4.2 \%$ of the needs of the local market in terms of electricity and heat consumption. Taking into account high forest cover of the region (40\%), the 60\% annual increment of total harvesting, and obtaining biomass at the level of $30 \%$ of the total harvesting, waste wood from the forest can meet $58.1 \%$ of the needs of the local market in terms of electricity consumption and $14.4 \%$ of the need for thermal energy consumption. There is a certain niche in the fuel wood market that is currently unused, presenting the opportunity to develop this sector and generate additional jobs in local markets. However, the increase in obtained forest biomass must be in accordance with the principles of sustainable development.
\end{abstract}

Keywords: renewable energy sources; woody biomass; fuelwood; slash for fuel; harvesting residues

\section{Introduction}

Renewable energy sources (RES), including biomass, are coming into focus as the demand to reduce the share of conventional fuels in the total energy production in EU countries becomes urgent $[1,2]$. The EU policy on $\mathrm{CO}_{2}$ emissions and maintaining energy security requires member states to produce $20 \%$ of energy from RES in 2020 [3]. Forest biomass is particularly important for energy production, accounting for $80 \%$ of the biomass used in the EU [4]; however, it is estimated to account for $50 \%$ of the total biomass potential in the EU [5]. In addition, in some regions of the EU, the potential of agricultural biomass is three times higher than that of forest biomass [6]. In 2012, EU countries used approximately 240 million tons of biomass for energy production [7]. It has been estimated that the demand for forest biomass is going to increase in the coming years [8-10]. The share of solid biomass in the overall structure of RES in Poland is as high as $68 \%$, of which over $90 \%$ is woody biomass [11]. Similarly, in Serbia [12], Sweden [9], and Finland [8], forest biomass is the main source of RES. In Poland, among all kinds of woody biomass acquired for energy purposes, the largest amount is wood directly obtained from forests. According to the National Bureau of Statistics, in 2017, it was 5 million $\mathrm{m}^{3}$ [13] (fuelwood, slash for fuel, and stump wood) and 7 million $\mathrm{m}^{3}$ including the more expensive medium-size wood, mainly used for paper production, but often purchased for heating purposes in the event of a fuelwood deficit in the local market. Other sources of woody biomass for energy purposes include energy crops and wood indirectly obtained from forests. In the short cycle, they include waste from the wood industry (lumber, shavings, wood chips, sawdust, and bark), while in 
the long cycle, they include waste from waste disposal-utilized wood (e.g., old furniture, windows, and door woodwork). Fuelwood is the dominant form of woody biomass in Poland. However, as the demand for RES is increasing, the raw material acquired from the forest in a form that does not require further processing is becoming more and more important-wood in the form of wood chips. The technological development of heating installations, which are installed using modern construction solutions, is also significant here. Currently, these installations are adapted to mainly burn wood shredded in the form of wood chips or processed in the form of pellets and briquettes, where fuel is fed automatically from the tank to the boiler. Forest management in terms of fuel wood acquisition needs to be adapted to market requirements. This may be achieved by introducing innovative solutions using a special construction of machines adapted to the skidding of shredded wood or bales intended for chipping, which ensures the most effective form of logging waste acquisition.

Polish authorities are obliged to determine the potential amount of energy that can be produced from RES. However, biomass energy potential is estimated and managed by including economic, technical, social, and environmental aspects on a regional scale [14]. Due to the growing demand for RES in the EU, questions regarding the amount of biomass potential from forests determined on a regional scale have become valid from the regional to European level [15].

Determining the energy potential of forest biomass and referring this amount to the needs of the local market in the environmental and economic conditions of Europe have been studied extremely rarely, and one of the very few examples is the work on optimizing the use of forest biomass for the energy supply at the regional level in a small mountain region of Italy [14]. The authors of this work emphasized that only $16 \%$ of the local market's energy needs can be met at acceptable costs using biomass combustion energy. This study deals with similar issues; however, unlike the above mentioned case, it was conducted in a lowland area of Poland. In addition, the Italian study mainly concerned deciduous species (beech, oak, chestnut, and conifer), while this study concerned Scots pine.

The aim of the present study was to determine the energy potential of forest biomass for energy purposes in the Janów Lubelski Forest District, south-eastern Poland. The study also compared this value with the electricity and heat energy consumption of the local market-Janów poviat. Additionally, in order to give the reader's a broader perspective on the potential of wood production in Poland, this paper presents results on the change in the stock of standing timber and the acquisition of total wood and fuel wood in recent years in Poland.

\section{Materials and Methods}

The number of inhabitants $(46,057)$ of the Janów district, number of people in a household $(2.8)$, and number of households $(16,449)$ were obtained from the National Bureau of Statistics data [16].

The north-west part of the area lies within the Lublin Upland, the north-east part within Roztocze, and the southern part within the Biłgoraj Plain, which belongs to the Sandomierz Basin. Such a location exhibits an overlapping of features characteristic for a given terrain. The river valleys cutting into the loess ground contrast with the gorges and ravines characteristic of Roztocze. The area, which is a part of the Biłgoraj Plain, is characterized by a large depression and little diversification of the terrain. The ponds, which together cover an area of 1800 hectares, provide a variable topography [17].

The soils of the area in question are formed, i.e., of Quaternary aeolian, dune, and hydro-glacial deposits. These soils are diversified and occur alternately, depending on the topography. Podzolic soils and glial soils dominate [17].

This area has a foothill lowlands and valleys climate, which is a cold temperate climate. The average annual air temperature is between +7.0 and $7.9^{\circ} \mathrm{C}$. The highest average temperature occurs in July $\left(+19.6^{\circ} \mathrm{C}\right)$, and the lowest in January $\left(-4.5^{\circ} \mathrm{C}\right)$. The average rainfall is estimated to be around $650 \mathrm{~mm}$, and the annual snow cover is around 68 days. In this area, the vegetation period lasts 219 days-it begins on around 7 April and ends around 11 November [17].

The Janów poviat is located in south-eastern Poland, which is a region where forests play an important role in the economy, generate many jobs, and supply the market with wood, including 
firewood. In this region, wood biomass is the basic source of heat for many households. On the one hand, this is due to the relatively lower income of households compared to western Poland or residents of larger urban agglomerations. The total income of the budget of the Janowski poviat per capita in 2018 amounted to $€ 296$. In comparison, in the west of Poland, e.g., in Wrocław, the value was $€ 1621$; in Szczecin, the value was $€ 1320$; and in Zielona Góra, the value was $€ 1532$ [16]. The eastern part of Poland is also characterized by higher unemployment than the western and large cities. Registered unemployment in 2018 in the Janowski poviat was 8.5\%. In comparison, the average for Poland was $5.8 \%$, and, e.g., in Wrocław, it was 1.9\%; in Szczecin, it was 2.6\%; and in Zielona Góra, it was 3.3\% [16]. The search for cheaper energy sources, such as forest biomass, may be connected to the greater number of unemployed people.

On the other hand, the selection of forest biomass as the basic fuel for heat production in the studied region results from the long-standing tradition of heating houses with wood and the strong relationship between inhabitants of smaller towns and the forest. The selected region is a good representative of eastern Poland - the eastern border of the European Union. Janów Lubelski Forest District (N: 50.6389-50.8424; E: 22.0277-22.6807) is located in SE Poland. Most of the Forest District is within the borders of the Janów poviat, which has a high forest coverage rate- $40.5 \%$. The Forest District area is $31,597.39$ ha, $97 \%$ of which is comprised of forests. It is dominated by less rich habitats of mixed forests (51\%) and coniferous forests (27\%). In total, $19 \%$ constitute more fertile mixed forest habitats and only $3 \%$ are the most fertile forest habitats. The most common stands are the Scots pine stands $(85.30 \%)$. Other species of greater importance are common fir (Abies alba Mill.) (5.56\%), black alder (Alnus glutinosa Gaertn.) (4.41\%), and silver birch (Betula pendula Roth) (2.09\%). Stands aged 61-100 years have the largest share in the age structure, which is typical for the area of Solska Forest-the western part of which consists of the forests of the Janów Lubelski Forest District [18].

The required data were obtained from the documentation of the Janów Lubelski Forest District and the data published annually by the National Bureau of Statistics $[13,16]$. The theoretical energy potential was calculated on the basis of the determined mass of individual assortments with the following formula:

$$
\mathrm{E}=\sum \mathrm{m} \cdot \mathrm{W}
$$

where $E$ is the fuel energy potential $(G J), m$ is the wood mass $(t)$, and $W$ is the calorific value $\left(G J t^{-1}\right)$.

The mass of fuel was calculated from the equation below:

$$
\mathrm{m}=\mathrm{V} \cdot \rho,
$$

where $\mathrm{V}$ is the fuel volume $\left(\mathrm{m}^{3}\right.$; in this paper, it is the sum of the volumes of slash for fuel and round fuelwood) and $\rho$ is the fuel density $\left(\mathrm{t} \mathrm{m}^{-3}\right)$.

The wood mass was calculated based on its density. This study indicates that pines with smaller diameters have a higher density than pines with larger diameters [19]. The density of wood also changes as its moisture fluctuates; the higher the moisture of wood, the higher its density [19], but also the lower its calorific value. This study assumed, after Krzysik [20], that $1 \mathrm{~m}^{3}$ of pine in an air-dry condition has a density of $500 \mathrm{~kg} \mathrm{~m}^{-3}$. The energy value of wood depends on the moisture content and density of the raw material, as well as its type and the method of processing. The calorific value of dry fuel wood is, on average, 19-22 GJ t ${ }^{-1}$ of dry matter [21,22]. However, when the moisture content of the raw material is $50 \%$ or more (freshly cut wood), the calorific value is only $6-7 \mathrm{GJ} \mathrm{t}^{-1}$ of fresh weight [23]. Wood fuel has a high content of volatiles that evaporate during the dry distillation or heating process [24]. Therefore, the calculations consider the calorific value of the pine in the air-dry state (seasoned wood) to be $14 \mathrm{GJ} \mathrm{t}^{-1}$, after Izdebski et al. [25]. The efficiency of the steam boiler was assumed to be $65 \%$ for heat production (energy potential heat production $=0.65 \mathrm{E}$ ) and $30 \%$ for electricity production (energy potential electricity production $=0.30 \mathrm{E}$ ) $[26,27]$. 
Next, the fuel cost- biomass $\left(\mathrm{C}_{\mathrm{f}}\right)$ was calculated by taking into account the round fuelwood $\left(\mathrm{C}_{\mathrm{rf}}\right)$ price in this Forest District at the level of $25 € \mathrm{~m}^{-3}$ and the price of slash for fuel $\left(\mathrm{C}_{\mathrm{sf}}\right)$ of $13 € \mathrm{~m}^{-3}$ $(1 €=4.3$ PLN was adopted).

$$
\mathrm{Cf}=\mathrm{Vrf} \cdot \mathrm{Crf}+\mathrm{Vsf} \cdot \mathrm{Csf}
$$

where $V_{\text {rf }}$ is the volume of round fuelwood $\left(\mathrm{m}^{3}\right)$ and $V_{\text {sf }}$ is the volume of slash for fuel $\left(\mathrm{m}^{3}\right)$.

Based on the determined energy potential of wood biomass, the extent to which the harvested energy wood meets the needs of the inhabitants of the Janów poviat in terms of the annual electricity or heat consumption was calculated. It is estimated that a household consumes approx. $7.8 \mathrm{GJ}$ of electricity and about $68 \mathrm{GJ}$ of heat energy per year [11]. Therefore, if a household uses $7.8 \mathrm{GJ}$ of electricity, then the input thermal requirement is $26 \mathrm{GJ}$ of heat to the steam boiler ( $30 \%$ efficient in converting heat to electricity). The thermal demand of the household faces a similar challenge, by taking into account the energy conversion efficiency of the wood stove in providing heat from the chemical energy in the wood. Typically, the efficiency is about $65 \%$, so the thermal demand is $105 \mathrm{GJ}$.

Therefore, the electricity demand (Ele) was calculated based on the equation Ele $=\mathrm{E} 26^{-1}$. Additionally, the demand for heat energy (The) was calculated as The $=\mathrm{E} 105^{-1}$.

Data on harvesting wood, including biomass for energy purposes, and changes in the stock of standing wood in the period from 2010 to 2017 in Poland were prepared on the basis of the National Bureau of Statistics [11,13].

\section{Results and Discussion}

An average of $12,810 \mathrm{~m}^{3}$ of fuel wood was obtained annually during the last 5 years in the forests of the Janów Lubelski Forest District (Table 1), which accounted for approx. 10.8\% of the total volume of harvest (Figure 1).

Table 1. Volume, mass, and energy potential of harvested woody biomass in the Janów Lubelski Forest District in 2015-2019.

\begin{tabular}{|c|c|c|c|c|c|c|c|}
\hline Year & $\begin{array}{c}\text { Slash } \\
\text { for Fuel } \\
\left(\mathrm{m}^{3}\right)\end{array}$ & $\begin{array}{c}\text { Round } \\
\text { Fuelwood } \\
\left(\mathrm{m}^{3}\right)\end{array}$ & $\begin{array}{c}\text { Volume of } \\
\text { Wood } \\
\text { Biomass }\left(\mathrm{m}^{3}\right)\end{array}$ & $\begin{array}{l}\text { Mass of Wood } \\
\text { Biomass (t) }\end{array}$ & $\begin{array}{c}\text { Theoretical } \\
\text { Energy } \\
\text { Potential (GJ) }\end{array}$ & $\begin{array}{l}\text { Energy Potential } \\
\text { Electricity } \\
\text { Production (GJ) }\end{array}$ & $\begin{array}{c}\text { Energy } \\
\text { Potential Heat } \\
\text { Production (GJ) }\end{array}$ \\
\hline 2016 & 2306 & 9477 & 11,783 & 5891 & 82,474 & 24,742 & 53,608 \\
\hline 2017 & 2499 & 10,748 & 13,247 & 6623 & 92,722 & 27,817 & 60,269 \\
\hline 2018 & 2240 & 11,600 & 13,840 & 6920 & 96,880 & 29,064 & 62,972 \\
\hline
\end{tabular}

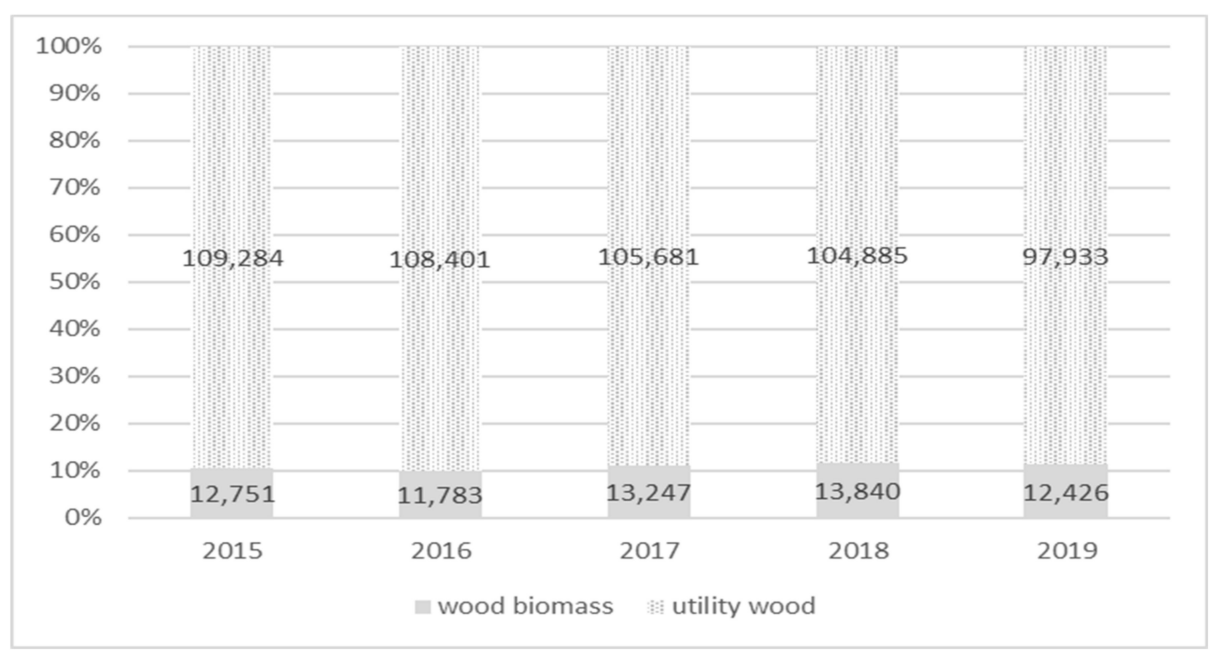

Figure 1. Wood harvested for energy purposes in $\mathrm{m}^{3}$ of the total volume of harvest in the Janów Lubelski Forest District in 2015-2019. 
The dominant group of fuel wood was low quality roundwood (82\%), and the remaining $18 \%$ constituted slash for fuel and forest residues (Table 1). The calculated energy potential of forest biomass is in the range of $82,474-96,880 \mathrm{GJ}$, with an average of $89,662 \mathrm{GJ}$ within the last 5 years and a fuel biomass cost of $€ 292,962$ (Table 2).

Table 2. Costs of heat and electricity produced from biomass obtained in the Janów Lubelski Forest District in 2015-2019.

\begin{tabular}{cccccc}
\hline \multirow{2}{*}{ Year } & \multirow{2}{*}{$\begin{array}{c}\text { Fuel } \\
\text { Cost-Biomass }(\boldsymbol{\epsilon})\end{array}$} & \multicolumn{2}{c}{ Cost of 1 GJ } & \multicolumn{2}{c}{$\begin{array}{c}\text { Annual Cost of Energy Production } \\
\text { for the Household }\end{array}$} \\
\cline { 3 - 6 } & & Electricity $(\boldsymbol{\epsilon})$ & Heat Energy $(\boldsymbol{\epsilon})$ & Electricity $(\boldsymbol{\epsilon})$ & Heat Energy (€) \\
\hline 2015 & 287,311 & 10.73 & 4.95 & 83.70 & 336.77 \\
2016 & 266,903 & 10.79 & 4.98 & 84.14 & 338.56 \\
2017 & 301,187 & 10.83 & 5.00 & 84.45 & 339.82 \\
2018 & 319,120 & 10.98 & 5.07 & 85.64 & 344.60 \\
2019 & 288,751 & 11.07 & 5.11 & 86.31 & 347.29 \\
Mean & 292,662 & 10.88 & 5.02 & 84.86 & 341.47 \\
\hline
\end{tabular}

The calculations performed in the study indicate that, in 2015-2019, an average of $6404 \mathrm{t}$ of wood biomass per year was obtained for energy purposes, and after its annual seasoning, the energy potential ranged from 82,474 to $96,880 \mathrm{GJ}$. The average value of the biomass energy potential of the Janów Lubelski Forest District, calculated for 2015-2019, corresponds to the needs of 3449 households for electricity during the year. According to the National Bureau of Statistics [16], the number of inhabitants of the Janów province, within which the Janów Lubelski Forest District is located, amounts to 46,057 inhabitants. The residents' homes consist of 2.8-person families, and the number of homes amounts to 16,449 . Therefore, the energy potential of the acquired forest biomass in the Janów Lubelski Forest District would be enough to provide electricity to $21.0 \%$ of residents of the Janów province. In the case of supplying homes with the energy needed to heat water and central heating, the calculated potential would meet the needs of 854 household (5.2\% of the total in the Janów province) (Figure 2). However, considering the combined consumption of electricity and heat, the acquired forest biomass would meet the needs of $4.2 \%$ of the households of the studied region. Given the increasing efficiency of biomass burning boilers, the progressive thermal insulation of houses and flats, and the increasing use of energy-saving light bulbs and home appliances, with the same volume of forest biomass harvesting, the electricity and heat produced from it will meet the needs of a larger number of inhabitants than before.

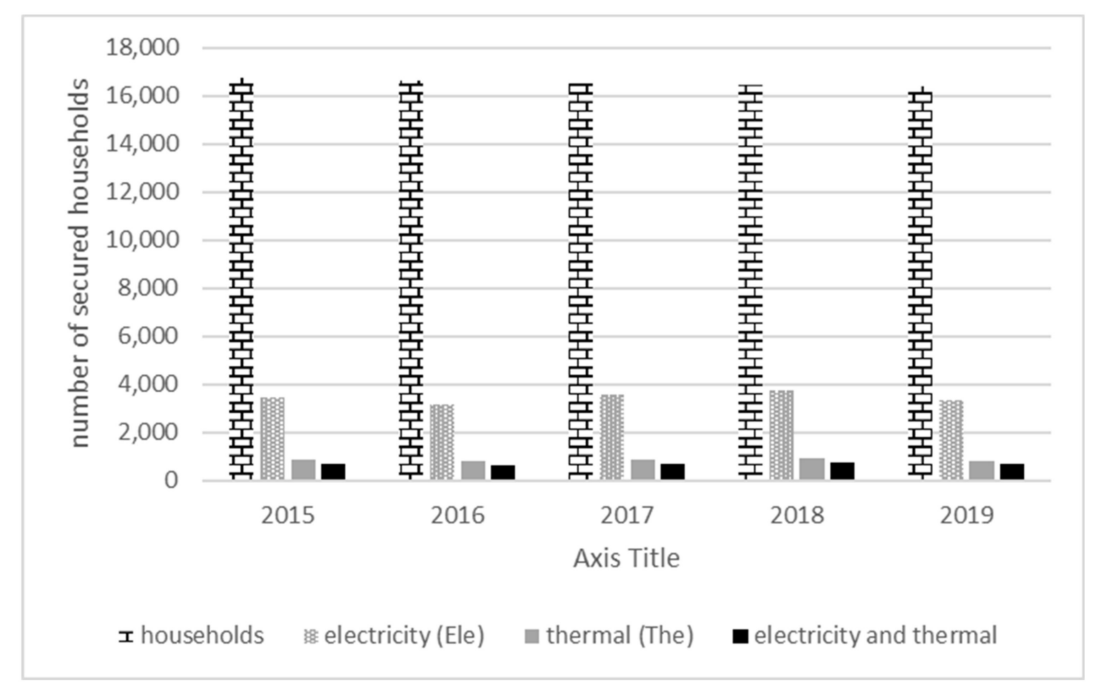

Figure 2. Satisfying the annual electricity or heat demands of the inhabitants of the Janów province with fuel wood harvested in the Janów Lubelski Forest District. 
This study proved that the share of fuel wood was only $10.8 \%$ of the total volume harvested in the Janów Lubelski Forest District during the last five years (2015-2019). Harvesting such a small amount of fuel wood may be attributed to the well-developed local processing industry and large amount of logging waste left that could serve as a valuable source of biomass for energy purposes.

Both slash for fuel and round fuelwood were harvested in the study area. During the five-year period analyzed, harvesting slash for fuel ranged from $1827 \mathrm{~m}^{3}$ (2019) to $2622 \mathrm{~m}^{3}$ (2015), while fuelwood was in the range of $9477 \mathrm{~m}^{3}$ (2016) to $11,600 \mathrm{~m}^{3}$ (2018). The volume of harvesting small-sized and medium-sized wood varied significantly. For example, in 2015, $2622 \mathrm{~m}^{3}$ of a small-sized assortment was obtained, while almost four times more of a medium-sized assortment was obtained, with a value of $10,129 \mathrm{~m}^{3}$. In the following years, the trend was similar. Such a state of affairs was present despite the much higher prices for round pine fuelwood than for harvesting residues. The price of fuelwood in this Forest District was set at $€ 25 \mathrm{~m}^{-3}$ and the price of harvesting residues was set at $€ 13 \mathrm{~m}^{-3}$ (assumed $€ 1=4.3 \mathrm{PLN}$ ). Furthermore, Moiseyev et al. [28] point out that harvesting residues are the cheapest source of wood biomass and should be used in the first place for energy and heat production. Trømborg et al. [29], when conducting a study in Norway on the supply and demand of forest biomass, also found that the cheapest source of wood biomass in energy production consists of chips from domestic harvesting residues. Paletto et al. [30] believe that, in addition to economic benefits, the use of wood chips also brings environmental benefits-the greater the share of local wood chips burned, the greater the benefits. The environmental impact of transport is smaller in this case.

A significant difference in fuel wood harvesting is observed in relation to the overall harvest volume. Wood harvested for energy purposes in the years 2015-2019 in the studied area amounted to $11,783 \mathrm{~m}^{3}$ (2016) to $13,247 \mathrm{~m}^{3}$ (2017). The total harvested volume was $120,184-118,928 \mathrm{~m}^{3}$, respectively. The data obtained indicated that the share of wood for energy purposes in these years was only $10.8 \%$. The remaining $89.2 \%$ of raw material obtained was used in the processing industry, in the paper industry, and on the construction market. Such a low share of fuel wood in the total harvested volume indicated a low utilization of the energy wood potential in this forest district. It is estimated that the share of useful wood constitutes $60 \%$ of harvested biomass in the forest, with the remaining $40 \%$ being biomass that can be obtained and used for energy purposes [25,31]. Therefore, the potential of fuel wood for the studied forest district was $44,143 \mathrm{~m}^{3}$ compared to just $12,427 \mathrm{~m}^{3}$ obtained in 2019. In turn, the share of fuel wood, at $10.8 \%$ in relation to the total harvested volume, was slightly lower than the long-term average for the State Forests in Poland, which was 11.3\% for 2003-2012 [32]. Such a result indicated a general tendency to leave a significant part of the biomass of harvested trees in the forest. In the management of state forests, the outdated formula employed for the sale of harvesting waste should be changed and the fuel wood offer needs to be adapted to modern market needs. There is a certain niche in the energy wood market that is currently unused, presenting the opportunity to develop this sector and generate additional jobs in local markets. Enterprises may be created or the existing Forestry Services Company may expand their offer to include buying harvesting waste and processing it into pellets or wood briquettes. The amount of harvesting waste left and the growing market demand for such fuel (more and more boilers with a feeder and a ban on burning coal in houses in some regions of Poland) represent reasons for this suggestion. In addition, this solution shortens the sales chain and limits the number of intermediaries, which, according to Spinelli et al. [33], is a key success factor in the profitability of wood biomass energy production on the local market. In the studied area, the average efficiency of fuel wood harvesting for the analyzed period was $0.42 \mathrm{~m}^{3} \mathrm{ha}^{-1}$ of forest, without taking into account medium-size wood. In Poland, according to National Bureau of Statistics data [16], about 5 million $\mathrm{m}^{3}$ of fuel wood is obtained annually, which means $0.54 \mathrm{~m}^{3} \mathrm{ha}^{-1}$ without medium-size wood. Including some medium-sized wood $\left(2\right.$ million $\left.\mathrm{m}^{3}\right)$ purchased by individual recipients for fuel in the calculation, a value of $0.76 \mathrm{~m}^{3} \mathrm{ha}^{-1}$ is obtained. A similar harvest of fuel wood has been observed in Serbia- $0.55 \mathrm{~m}^{3} \mathrm{ha}^{-1}$ [12]. In contrast, a much higher value of $0.82-1.00 \mathrm{~m}^{3}$ $\mathrm{ha}^{-1}$ was obtained in Moldova [34]. Therefore, it can be concluded that the efficiency of fuel wood harvesting in the studied area was low and only ensured the needs of $4.3 \%$ of the local market in 
terms of electricity and heat consumption. Freppaz et al. [14] presented much higher results from the mountainous region of Italy, stating that only $16 \%$ of the energy demand can be met by burning wood biomass obtained locally.

If such a large disproportion is observed between the amount of wood harvested for fuel and the total harvested volume, it should be assessed whether, due to the small amount of raw material intended for fuel, its management is correct. If raw material is not abundant, harvesting loss will be minimized-in the case of forest biomass, not only pile wood, but also brushwood and stump wood, should be obtained, and as many shavings and sawdust as possible should be kept during processing. With this assumption, the entire energy potential of the raw material could be used, which is not the case today. Of course, this approach may not apply to the poorest habitats, since a decrease in nitrogen, phosphorus, potassium, calcium, and magnesium is observed in forest environments where wood biomass is frequently harvested. It is obvious that nutrients removed from the soil can be replaced with mineral fertilizers; however, soil without a humus layer is susceptible to eluvial processes, which often have irreversible consequences. For the protection of habitats, it is important that leaves and bark remain in the forest, in which the most macro- and micro-components are accumulated [35]. Novák et al. [36] additionally postulate leaving belowground biomass (stumps and coarse roots), especially in poor habitats. The need for the sustainable acquisition of forest biomass for energy purposes is also highlighted by Frombo et al. [37]. Another way to protect habitats against nutrient depletion is fertilization with wood ash [38].

As not all possible resources of forest biomass are currently obtained, there is still a certain pool of fuel wood that can supply the growing market for RES. However, before the biomass of harvested trees is used to increase energy production, it should be determined in which habitats it would be possible to increase the acquisition of biomass from harvesting waste without introducing a greater risk of its impoverishment. The increase in fuel wood harvesting cannot be the aim in itself and it must be carried out in accordance with the principles of sustainable development in forest management. Wood directly obtained from the forest, intended for the renewable energy market, should only come from planned care, forest protection, including disaster damage recovery and forest renewal. Only raw material of an inferior quality that is not usable as utility wood (for the production of objects made of wood, furniture, houses, paper, and others) can be used for energy purposes. One of the obstacles to increasing the use of forest biomass for energy purposes in Poland is the insufficient equipment of Forestry Services Company, with modern equipment enabling, e.g., the harvesting of stump wood or acquirement of wood chips and the production of pellets or briquettes from logging residues. Given the moisture content and energy balance, it is suggested that the treatment methods should be based on the direct fragmentation of wood biomass immediately after cutting [39]. In many places, harvesting residues are left in the forest. The reason for this is the outdated formula employed for obtaining this raw material by the so-called "self-product" (the buyer must prepare the wood piles from harvesting waste and then remove the wood from the forest by their own transport), which is of no interest to potential buyers. Such a sales formula, due to the lower costs of purchasing fuel wood from harvesting residues, was valid until the late 1990s, when most households in the countryside had a tractor or a horse and there was high unemployment in Poland. Today's recipient of fuel wood is interested in raw material delivered to the house which does not require further processing, for which buyers are willing to pay more.

Despite the insufficient use of forest biomass resources in Poland, the forecasts regarding its harvesting for energy purposes are optimistic [25]. Taking into account the forest area (9.2 million ha) and the continuous increase of the stocks of standing wood (Figure 3), the forest biomass will remain the main source of RES in Poland for a long time, as in other European countries with a large forest area, mainly in Sweden [9] and Finland [8]. Additionally, this is supported by its competitive price in relation to fossil fuels. Assuming that the cost that needs to be incurred when heating a house with wood is $100 \%$, then in the case of other energy sources, the prices would be as follows: Coal- $150 \%$; heating oil-175\%; and electricity (in Poland, mainly produced from coal) $-550 \%$ [40]. This paper 
has indicated that the cost of fuel/biomass needed to produce $1 \mathrm{GJ}$ of electricity calculated as the average for the last 5 years was $€ 10.88$ and that for heat energy was $€ 5.02$ (Table 2). Given that the average household in Poland consumes about $76 \mathrm{GJ}\left(18.7 \mathrm{~m}^{3}\right.$ wood biomass) of electricity and heat annually, the cost of fuel/biomass needed to produce this energy would be $€ 426$, of which $€ 341$ is for heat (Table 2). Therefore, wood compared to fossil fuels remains the most beneficial source of energy, for both ecological and economic reasons. However, according to Paschalis-Jakubowicz [41], making such a statement with the current state of knowledge is risky. He believes that the costs of obtaining energy from forest biomass are understated because they do not take into account, i.e., environmental losses that are currently difficult to measure. However, it should be noted that when producing energy from fossil fuels, not all environmental costs are taken into account; only those associated with excessive $\mathrm{CO}_{2}$ emissions. However, there are doubts about the so-called zero carbon emissions when burning wood. Such a zero emission result can only take place while maintaining the continuity of wood production - forest farming - in a given area, taking into account the long life cycle of the forest. Nevertheless, the results of Buonocore et al. [42] and Nikodinoska et al. [43] clearly indicate up to 10 times lower $\mathrm{CO}_{2}$ emissions when burning wood compared to burning fossil fuels and the same power plant capacity.

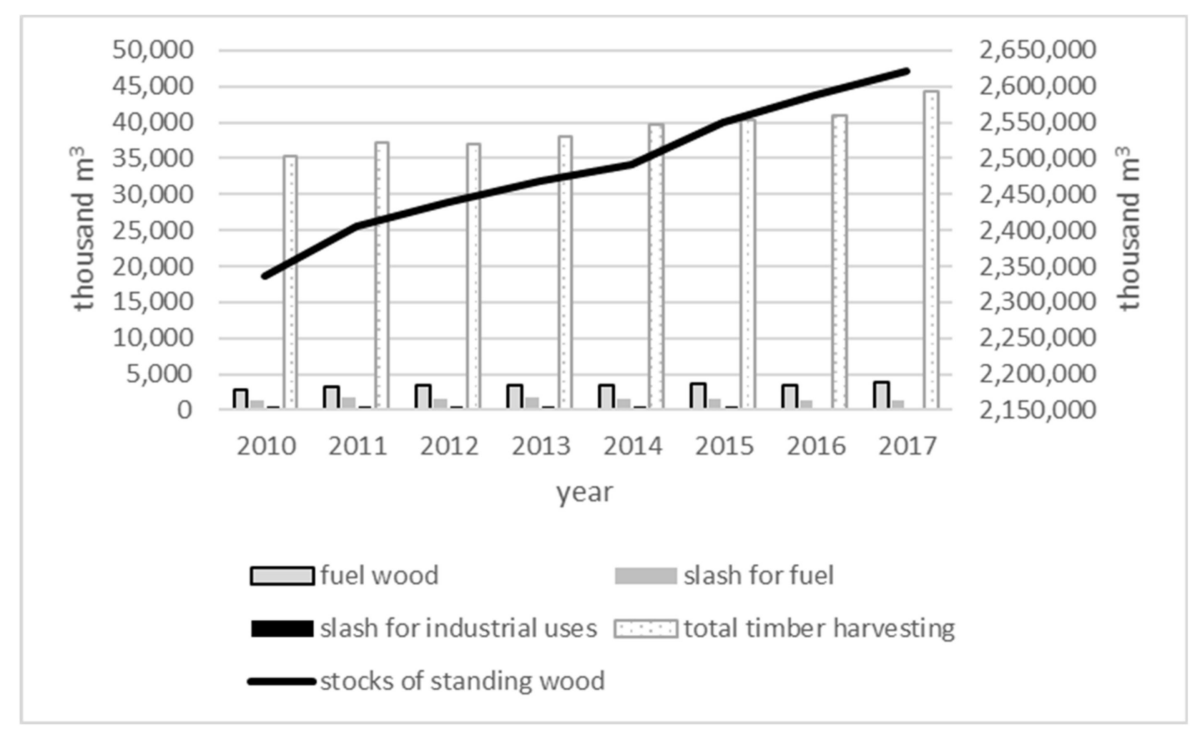

Figure 3. Harvesting wood, including biomass, for energy purposes, and changes in the stocks of standing wood from 2010 to 2017 in Poland. Own study based on the National Bureau of Statistics [13,44].

The limitations of the presented research leave some questions unanswered, thus setting directions for further research, e.g., estimations of external effects of the wood biomass used in comparison to other energy sources, such as coal, oil, and gas. The following questions may be addressed: What are the consequences for the local environment of using energy from wood biomass instead of other sources? What may the market expectation be in the changing socio-economic, technological, and political conditions?

\section{Conclusions}

The current level of forest biomass harvesting for energy purposes $(10.8 \%$ of total harvest, i.e., $25 \%$ of forest biomass obtainable) in the Janów Lubelski Forest District secures $4.2 \%$ of the needs of households of the Janów poviat in terms of electricity and heat consumption. Increasing biomass acquisition to 30\% (10\% still in the forest: Green branches with needles, snags, and roots), especially harvesting waste currently left behind, would allow $58.1 \%$ of the needs of households of the studied region to be met in terms of electricity consumption and nearly $14.4 \%$ in terms of heat energy consumption. 
In sum, given the high forest cover (40\%), the approx. $60 \%$ annual increment of total harvested wood, and harvesting biomass for energy purposes at the level of $30 \%$ of total harvest, forest harvesting residues can meet $11.5 \%$ of the local market needs (46,000 inhabitants) in terms of electricity and heat consumption.

The results provide the characteristics of the region's forests, including the forest cover, the average age of stands, and the percentage of volume obtained for the tree rings of tree stands. Thanks to this, apart from the direct value of the results for the examined region of the eastern border of the EU, the results can be successfully applied to other regions with similar forest characteristics. In addition, the paper describes changes in the stock of wood of tree stands and the volume of wood harvested, including the group of energy wood in Poland in recent years. The results indicate the need for changes in the logging waste sales policy, in order to adapt the offer to the current market needs. There is a certain niche in the energy wood market that is currently not used, presenting the opportunity to develop this sector and generate additional jobs in local markets in countries such as Poland.

Funding: This research received no external funding.

Acknowledgments: I would like to thank Eng. Natalia Cholewa and the staff of the Janów Lubelski Forest District for help in providing data related to the volume of wood harvested in the forests in the analyzed region.

Conflicts of Interest: The author declares no conflict of interest.

\section{References}

1. Eurostat Energy. Energy Statistics-Quantities (Nrg_Quant). Available online: https://ec.europa.eu/eurostat/ web/energy/data/database (accessed on 8 June 2020).

2. Picchio, R.; Latterini, F.; Venanzi, R.; Stefanoni, W.; Suardi, A.; Tocci, D.; Pari, L. Pellet Production from Woody and Non-Woody Feedstocks: A Review on Biomass Quality Evaluation. Energies 2020, 13, 2937. [CrossRef]

3. EU. Directive 2009/28/EC of the European Parliament and of the Council of 23 April 2009 on the Promotion of the Use of Energy from Renewable Sources and Amending and Subsequently Repealing Directives 2001/77/EC and 2003/30/EC. OJ. L 140 2009, 5-6, 16-62.

4. Proskurina, S.; Sikkema, R.; Heinimö, J.; Vakkilainen, E. Five years left-How are the EU member states contributing to the $20 \%$ target for EU's renewable energy consumption; the role of woody biomass. Biomass Bioenergy 2016, 95, 64-77. [CrossRef]

5. Elbersen, B.; Startisky, I.; Naeff, H.; Hengeveld, G.; Schelhaas, M.J.; Böttcher, H. Spatially Detailed and Quantified Overview of EU Biomass Potential Taking into Account the Main Criteria Determining Biomass Availability from Different Sources. Deliverable 3.3-Project: Biomass Role in Achieving the Climate Change \& Renewables EU Policy Targets. Demand and Supply Dynamics under the Perspective of Stakeholders 2010. IEE 08653 SI2. 529 241. Available online: https://ec.europa.eu/energy/intelligent/projects/sites/iee-projects/files/projects/documents/ biomass_futures_atlas_of_technical_and_economic_biomass_potential_en.pdf (accessed on 6 July 2020).

6. Fernandes, U.; Costa, M. Potential of biomass residues for energy production and utilization in a region of Portugal. Biomass Bioenergy 2010, 34, 661-666. [CrossRef]

7. Scarlat, N.; Dallemand, J.-F.; Monforti-Ferrario, F.; Nita, V. The role of biomass and bioenergy in a future bioeconomy: Policies and facts. Environ. Dev. 2015, 15, 3-34. [CrossRef]

8. Karhunen, A.; Laihanen, M.; Ranta, T. Supply and Demand of a Forest Biomass in Application to the Region of South-East Finland. Smart Grid Renew. Energy 2012, 3, 34-42. [CrossRef]

9. Börjessona, P.; Hansson, J.; Berndes, G. Future demand for forest-based biomass for energy purposes in Sweden. For. Ecol. Manag. 2017, 383, 17-26. [CrossRef]

10. Haddad, S.; Britz, W.; Börner, J. Impacts of increased forest biomass demand in the European bioeconomy 57th annual conference of the GEWISOLA. In Proceedings of the Bridging the Gap between Resource Efficiency and Society's Expectations in the Agricultural and Food Economy, Munich, Germany, 13-15 September 2017. [CrossRef]

11. National Bureau of Statistics of the Republic of Poland. Energy Consumption in Households in 2015; Statistics Poland: Warszawa, Poland, 2017; ISSN 2084-8137. 
12. Janevski, J.N.; Stojanović, B.V.; Laković, M.S.; Stojiljković, M.M.; Mitrović, D.M. Wood biomass in Serbia-Resources and possibilities of use. Energy Source Part B 2016, 11, 732-738. [CrossRef]

13. National Bureau of Statistics of the Republic of Poland. Statistical Yearbook of Forestry; Statistics Poland: Warszawa, Poland, 2018; ISSN 2657-3199.

14. Freppaz, D.; Minciardi, R.; Robba, M.; Rovatti, M.; Sacile, R.; Taramasso, A. Optimizing forest biomass exploitation for energy supply at a regional level. Biomass Bioenergy 2004, 26, 15-25. [CrossRef]

15. Mantau, U.; Gschwantner, T.; Paletto, A.; Mayr, M.L.; Blanke, C.; Strukova, E.; Avdagic, A.; Camin, P.; Thivolle-Cazat, A.; Döring, P.; et al. From inventory to consumer biomass availability-the ITOC model. Ann. For. Sci. 2016, 73, 885-894. [CrossRef]

16. National Bureau of Statistics of the Republic of Poland. Demographic Yearbook of Poland; Statistics Poland: Warszawa, Poland, 2019; ISSN 1505-6716.

17. Environmental Protection Program for the Janów Poviat; Poviat Starosty Janów Lubelski: Janów Lubelski, Poland, 2003; p. 145. (In Polish)

18. Forest Management Plan, Plan for the Janów Lubelski Forest District forests for 2010-2019. 2009.

19. Tomczak, A.; Wesołowski, P.; Jelonek, T.; Jakubowski, M. Utrata masy i zmiany gęstości średniowymiarowego surowca sosnowego pozyskanego i magazynowanego w okresie letnim (Weight loss and green density changes of Scots pine pulpwood harvested and stored during the summer). Sylwan 2016, 160, 619-626. (In Polish) [CrossRef]

20. Krzysik, F. Nauka o Drewnie (Wood Science); PWN: Warszawa, Poland, 1978; p. 653. (In Polish)

21. Ragland, K.W.; Aerts, D.J. Properties of Wood for Combustion Analysis. Bioresour. Technol. 1991, 37, 61-168. [CrossRef]

22. Munalula, F.; Meincken, M. An evaluation of South African fuelwood with regards tocalorific value and environmental impact. Biomass Bioenergy 2009, 33, 415-420. [CrossRef]

23. Suadicani, K.; Gamborg, C. Fuel quality of whole-tree chips from freshly felled andsummer dried Norway spruce on a poor sandy soil and arich loamy soil. Biomass Bioenergy 1999, 17, 199-208. [CrossRef]

24. Bridgemana, T.G.; Jonesa, J.M.; Williamsa, A.; Waldron, D.J. An investigation of the grindability of two torrefied energy crops. Fuel 2010, 89, 3911-3918. [CrossRef]

25. Izdebski, W.; Jadeszko, P.; Skudlarski, J.; Zając, S. Analiza możliwości pozyskania biomasy leśnej na cele energetyczne na przykładzie nadleśnictwa Pomorze (Analysis of acquisition possibilities of forest biomass for energy purposes on the example of forest District Pomerania). Motrol 2011, 13, 157-163. (In Polish)

26. Bauen, A.; Berndes, G.; Junginger, M.; Londo, M.; Vuille, F. Bioenergy—A Sustainable and Reliable Energy Source; IEA Bioenergy: Paris, France, 2009; Available online: http://indiaenvironmentportal.org.in/files/Bioenergy_ a\%20sustainable_and_reliable_energy_source.pdf (accessed on 9 September 2020).

27. Zaporowski, B. Nowoczesne technologie skojarzonego wytwarzania energii elektrycznej i ciepła (Modern cogeneration technologies). Energy Policy J. 2017, 20, 41-54. (In Polish)

28. Moiseyeva, A.; Solberga, B.; Kalliob, A.M.I.; Lindner, M. An economic analysis of the potential contribution of forestbiomass to the EU RES target and its implications for the EU forest industries. J. For. Econ. 2011, 17, 197-213. [CrossRef]

29. Trømborg, E.; Havskjold, M.; Lislebø, O.; Rørstad, P.K. Projecting demand and supply of forest biomass for heating in Norway. Energy Policy 2011, 39, 7049-7058. [CrossRef]

30. Palettoa, A.; Bernardia, S.; Pierattia, E.; Testonb, F.; Romagnoli, M. Assessment of environmental impact of biomass power plants to increase thesocial acceptance of renewable energy technologies. Heliyon 2019, 5, e02070. [CrossRef]

31. Hall, J.P. Sustainable production of forest biomass for Energy. For. Chron. 2002, 78, 391-396. [CrossRef]

32. Parzych, S. The potential opportunities for using wood biomass in energy production. For. Res. Pap. 2015, 76, 256-264. [CrossRef]

33. Spinelli, R.; Pari, L.; Magagnotti, N. New biomass products, small-scale plants and vertical integration as opportunities for rural development. Biomass Bioenergy 2018, 115, 244-252. [CrossRef]

34. Karakosta, C.; Dimopoulou, S.; Doukas, H.; Psarras, J. The potential role of renewable energy in Moldova. Renew. Energy 2011, 36, 3550-3557. [CrossRef]

35. Manolis, E.N.; Zagas, T.D.; Karetsos, G.K.; Poravou, C.A. Ecological restrictions in forest biomass extraction for a sustainable renewable energy production. Renew. Sustain. Energy Rev. 2019, 110, 290-297. [CrossRef] 
36. Novák, J.; Dušek, D.; Kacálek, D.; Slodičák, M. Analysis of biomass in young Scots pine stands as a basis for sustainable forest management in Czech lowlands. J. For. Sci. 2017, 63, 555-561. [CrossRef]

37. Frombo, F.; Minciardi, R.; Robba, M.; Rosso, F.; Sacile, R. A dynamic decision model for the optimal use of forest biomass for energy production. Energy Syst. 2016, 7, 615-635. [CrossRef]

38. Varnagirytė-Kabašinskienė, J. Toward the rational use of forest biomass: Lithuanian case study. J. For. Sci. 2012, 58, 465-471. [CrossRef]

39. Pari, L.; Bergonzoli, S.; Cetera, P.; Mattei, P.; Alfano, V.; Rezaei, N.; Suardi, A.; Toscano, G.; Scarfone, A. Storage of Fine Woodchips from a Medium Rotation Coppice Eucalyptus Plantation in Central Italy. Energies 2020, 13, 2355. [CrossRef]

40. Moskalik, T.; Nowacka, W.; Sadowski, J.; Zastocki, D. Rynek drewna energetycznego w Polsce jako element rozwoju regionalnego (Wood energy market in Poland as part of regional development). Studia Mater. CEPL 2012, 32, 222-230. (In Polish)

41. Paschalis-Jakubowicz, P. Biomasa leśna jako odnawialne źródło energii-konsekwencje dla leśnictwa (Forest biomass as a renewable energy source-consequences for forestry). Sylwan 2018, 162, 688-695. (In Polish) [CrossRef]

42. Buonocore, E.; Paletto, A.; Russo, G.F.; Franzese, P.P. Indicators of environmental performance to assess wood-based bioenergy production: A case study in Northern Italy. J. Clean. Prod. 2019, 221, 242-248. [CrossRef]

43. Nikodinoska, N.; Cesaro, L.; Romano, R.; Paletto, A. Sustainability metrics for renewable energy production: Analysis of biomass-based energy plants in Italy. J. Renew. Sustain. Energy 2018, 10, 043104. [CrossRef]

44. National Bureau of Statistics of the Republic of Poland. Statistical Yearbook of Forestry; Statistics Poland: Warszawa, Poland, 2015; ISSN 1230-574X.

(C) 2020 by the author. Licensee MDPI, Basel, Switzerland. This article is an open access article distributed under the terms and conditions of the Creative Commons Attribution (CC BY) license (http://creativecommons.org/licenses/by/4.0/). 